\title{
Connecting experiences to employability through a meaning- making approach to learning
}

\author{
Andrea Reid ${ }^{1}$, Anna Richards ${ }^{2}$ and Dino Willox ${ }^{2}$ \\ Corresponding author: Andrea Reid (andreajreid@hotmail.com ) \\ ${ }^{1}$ University of Southern Queensland, Australia \\ ${ }^{2}$ The University of Queensland, Australia
}

\begin{abstract}
A key part of the student experience in the higher education context is employability. There is an expectation that universities will contribute to their students' employability and indeed they are measured on this contribution and are allocated funding based on it. Despite the importance of employability in higher education, it remains a complex and contested concept, often conflated with employment - graduates in jobs and the roles they occupy - and seen as a quantifiable outcome of the student experience. Where employability is understood as an individual's knowledge, capabilities, and personal attributes that make them more likely to gain employment and be successful in their professional lives, it is often framed by the discourse of skills. There are some employability models, however, that champion a more holistic view of employability and highlight the role that experiences play in individual employability development. This paper reports on the development of an institutional employability framework and reflective process in an Australian research-intensive university. The paper discusses the experiential learning theories that underpin the reflective process that supports students to understand and articulate employability learning, for framing narratives around the potential to contribute to an organisation for employment, and for the transfer of this potential to professional contexts. The framework and reflective process represent employability as a learning process through which students make meaning from their experiences and learning opportunities. This involves understanding the value of their experiences, how to articulate that value, and how to transfer it to workplace performance.
\end{abstract}

Keywords:

employability

learning, experiential

learning, reflection, meaningmaking, experiences, transfer, employability narratives

\section{Introduction}

Graduate employability continues to be a key issue on the higher education agenda and there is ongoing debate about graduates' work-readiness and their potential to contribute to the economy through work (Tomlinson, 2017). Employability is a multifaceted concept, including the skills, understandings and personal attributes that support graduates to gain employment and contribute to organisations and to society (Yorke, 2006). Employability is distinct from but related to employment (Holmes, 2017), the latter denoting the numbers of graduates in jobs and the types of jobs they occupy. In Australia and the UK, universities are judged on proxy measures of employment and are allocated government funding based on these measures (Cole \& Willox, 2021; Department 
of Education, Skills and Employment, 2020). While employability generally refers to the activities and pedagogies that support personal and professional growth (Dacre Pool, 2017), it remains a complex and contested concept with no universally recognised measures (Behle, 2020). It often focuses on individual potential while paying less attention to how this potential may be realised as job outcomes and the social and economic influences on these outcomes (Tomlinson, 2017). What is clear, however, is the expectation that universities should be made accountable for their students' employability development (Behle, 2020; Matherly \& Tillman, 2019).

Existing models and frameworks, in attempting to make sense of the complexity of employability, provide conceptualisations of individual employability and/or the construct of employability itself. Behle's framework (2020) acknowledges the influences of individual factors and circumstances, enabling support systems and the labour market on employability. There are two models that set out the components of individual employability. One of these is the Understanding, Skills, Efficacy beliefs, and Metacognition model (USEM) (Yorke \& Knight 2004) and the other is the CareerEDGE model (Dacre Pool \& Sewell, 2007), where EDGE represents Experience (work and life), Degree subject knowledge, Generic skills, and Emotional intelligence. These models signify a shift away from the prevailing skills discourse to view employability as a set of interrelated elements, thus exemplifying the 'things' students need to develop to become employable. Importantly, these models and frameworks show that employability is more than just discipline knowledge and skills.

The CareerEDGE model champions the role of work and life experience in the development of graduate employability (Dacre Pool \& Sewell 2007). Activities such as volunteering, internships, leadership programs, mentoring, and international study offer life-experience learning opportunities that provide the potential to facilitate employability development (Nghia, 2017; Purcell et al, 2012). These activities have been shown to contribute to employment outcomes (Clark et al, 2015; Lau, Hsu, Acosta \& Hsu, 2014). Life experiences are valuable, as they often present students with complexity, challenge, and the risk of failure (Curran, 2007). Activities outside of formal learning environments are fertile ground for the development of employability capabilities, but also intangible qualities and behavioural characteristics that are difficult to assess (Cushing et al, 2019, p. 205) but are vital to becoming an employable graduate.

The creators of CareerEDGE (Dacre Pool \& Sewell, 2007) contend that universities should provide students with opportunities to develop the elements of their model through reflection and evaluation. This idea aligns with the key tenets of experiential learning theory (ELT), where experience is the basis and stimulus for learning (Boud, Cohen, \& Walker, 1993) and making meaning from experiences leads to learning (Merriam \& Bierema, 2013; Mezirow, 2000). In contrast to classroom and work-integrated learning opportunities, life experiences (i.e. informal and extracurricular) are unstructured and often not assessed or certified (Richardson, 2004). The literature acknowledges this as a challenge (Montrose, 2002; Strange \& Gibson, 2017), where the difficulty lies in students understanding what they have gained from an unstructured experience and how this learning contributes to their personal and professional growth. These challenges create a solid platform for creating a reflective process to support students to make meaning from extra-curricular experiences for employability learning. This paper reports on the development and implementation of an institutional employability framework and a theoretically-framed reflective process that forms a key part of the implementation of the framework.

\section{Experiential learning approaches to employability development}

As an educational philosophy, experiential learning theory (ELT) is grounded in the idea that life experiences, education and work are pivotal to the learning and understanding of new knowledge and capabilities (Fry, Ketteridge, \& Marshall, 2009). Indeed, the fundamental place of experience in learning is central to understandings of adult learning (Merriam \& Bierema, 2013). In the 1980s, Kolb (1984) conceptualised the experiential learning process in a model that is now the most widely cited (Morris, 2020). This model shows learning from experience as a process of the learner engaging with 
an experience, observing and reflecting on the experience, using their analytical skills to integrate concepts and ideas from these observations, and then applying new ideas and concepts to practice. While there have been criticisms of Kolb's work, particularly the way it disregards the social context of learning, it remains a fundamental and influential model and the clearest expression of experiential learning theory (Seaman, Brown, \& Quay, 2017, p. 3).

When learners work through Kolb's experiential learning process, they are undertaking meaning making work to translate experiences into learning (Mezirow, 2000). Meaning-making is the process by which people interpret situations, events, objects, or discourses, in the light of their previous knowledge and experience (Zittoun \& Brinkmann, 2012, para. 1). Meaning-making involves rendering an experience coherent (Kegan, 1982; Mezirow, 2000) and determining the personal value or significance of the experience (Huta, 2017; Park, 2017). An experience takes on semiotic shape through meaning-making which makes emotionally-laden life experiences...thinkable and communicable (Zittoun \& Brinkmann, 2012, para. 8). Meaning-making requires learners to utilise language to articulate their experiences, both to themselves and to others (Mezirow, 2000). Importantly, meaning-making is socially and contextually influenced and learners themselves are social constructs (Jarvis, 1987). The meanings made from experiences are shaped by the nature of the experience and the learner's socially-constructed meaning-making lens. In this way, knowledge is situated in context: emphasising place and time (Morris, 2020, p. 1068).

In the context of employability learning, meaning-making allows the learner to construct authentic narratives that are important for articulating employability to potential employers. These narratives provide a mechanism for graduates to lay claim to the knowledge, skills, attributes and mindsets that are required for employability, and they are part of identity construction (de Blaquiere, Nolan \& Wray, 2019). Indeed, meaning-making is identity work (Erichsen, 2011) as it allows the learner to understand changes to their sense of self and their capabilities as a result of constructing meaning from experiences (Reid, 2020). Employability narratives are defined by de Blaquiere, Nolan and Wray (2019) as the articulation of skilful practices which demonstrate competent performance of skills in context, thus storying employability and supporting the development of a sense of identity as an employable graduate who perceives what she can offer to an employer expressed in terms an employer will understand (p.29). This makes meaning-making for employability learning highly socially and contextually framed, as learners are constructing and articulating meaning from experiences for personal growth framed as employability narratives that express their identity as employable graduates.

To help employers recognise the value of extra-curricular experiences in the recruitment process, it is important for students to determine what they have learned from these experiences and, in the case of outward-bound mobility, re-story 'travel stories' as 'career stories' (Green, King, \& Gallagher, 2019, p. 34). The same could be said about any experience that occurs outside of formal learning contexts, where stories represent graduates' perceptions of their employability, or their identity as beginning professionals who can create societal and organisational impact through employment (de Blaquiere et al., 2019; Oguro \& Mueller, 2020). Holmes (2013) argues that graduate identity should frame perspectives on employability, where a sense of the professional self is validated in workplace settings through the performance of the required skills and capabilities. Employment is not the only way that graduates transfer and apply learning from their higher education experiences. Universities, however, are positioned as being highly integral to economic prosperity, and the corollary is that graduates are key players on the economic stage with an integral part to play in the labour market (Tomlinson, 2017, p. 2). Moreover, while students have a range of reasons for attending university, job and career motivations are strong, particularly as tuition fees are high, and may rise in the future (Kaye $\&$ Bates, 2017).

While Holmes (2017) makes an argument for conceptualising employability as graduate identity, the language of skills is inherent in employers' expectations of graduates and in their recruitment practices (de Blaquiere et al., 2019). Employability, however, is more than just 'possession' of a set of skills. Graduates need to understand what to do with these skills to make an impact on the 
organisations in which they work, i.e. to turn these 'here and now' skills into future-focussed capabilities. The reality, though, is that success in the recruitment process is based largely on a graduate's ability to express what they can offer an employer using the language of skills and present compelling examples of those skills in practice (de Blaquiere et al., 2019). Moving beyond recruitment to the practice of work requires the learner to make meaning from their experiences and connect those meanings to personal and professional development. The learner needs to understand the potential utilisation of this development. One of the challenges is that students may not have given much thought to the learning potential of these experiences nor to the nature of their professional identity, career development and management and how to articulate what they can offer in job interviews or in the workplace itself (Oguro \& Mueller, 2020). The reflective process presented in this paper addresses this challenge.

\section{A new approach to student employability development}

The development of a reflective process to support students to understand and articulate employability learning from non-formal experiences was situated in the work on the University of Queensland's (UQ) student employability framework (Reid, 2015). The university is one of the Group of Eight research-intensive universities in Australia which, at the time, had no formal, shared approach to student employability development. The framework acknowledges that students develop discipline-based skills and knowledge through their degree studies and the degree is something that is taken for granted by employers and the first step in the application process (Brown, Hesketh, \& Williams, 2003). The framework is underpinned by work on graduate employability (Holmes, 2013; Jackson, 2016; Trede, Macklin, \& Bridges, 2012) that recognises the contribution of curricular learning and participation in activities provided by the university and the community to professional identity development (Oguro \& Mueller, 2020).

\section{Methodology}

The aim of the research was to provide an evidence base for the university's employability work. A small consultative, qualitative study was undertaken with human resources (HR) professionals using semi-structured interviews and a short online survey. These research instruments sought to ascertain expectations of graduates and perceptions of graduate performance. As this was a practice-based project, ethics approval was not required. In total, $28 \mathrm{HR}$ professionals were recruited for the study through professional networks to represent a broad range of graduate positions. Nineteen people were interviewed and nine completed the survey. The sample included recruiters and graduate program facilitators in medium and large organisations in the fields of health, engineering, local government, and business. A thematic approach (Braun \& Clark, 2006) was taken to the data analysis process.

\section{Findings}

The themes that emerged from the findings aligned with the literature on the need for students to be 'more than just their degree', that professional mindsets and capabilities underpinned by personal attributes and behavioural characteristics connect degree learning to effective workplace performance (Ortlieb, 2015). The findings also echoed the employability research on the value of extra-curricular activities (Clark et al., 2015; Purcell et al., 2012) and on broader conceptions of employability (Holmes, 2013; Tomlinson, 2017; Yorke, 2006).

The findings speak to the nature of graduate recruitment, where graduates lack professional work experience and are therefore usually selected for their perceived potential rather than a demonstrable capacity to perform in a particular role (Caballero \& Walker, 2010). Recruiters draw on a range of selection techniques to connect past achievements and behaviours to the role they need to fill, where this past performance is seen as an indicator of future workplace performance 
(Caballero \& Walker, 2010; Tomlinson, 2017). Graduates need to be able to draw on a range of experiences to effectively address behavioural interview questions and demonstrate workplace potential by making convincing claims about their professional identity and the attributes and characteristics that make them employable (de Blaquiere et al., 2019).

As the findings revealed the value of experiences to employability development, literature on ELT (e.g. Kolb, 1984) and adult learning (e.g. Merriam \& Bierema, 2013) was reviewed and key concepts were synthesised with the findings. The literature that underpins the employability framework and reflective process is discussed below.

\section{The UQ employability framework}

The work was focussed on providing a framework for understanding and articulating employability learning, for framing narratives around the potential to contribute to an organisation for employment and for application of this potential. The framework represents employability as a learning process through which students make meaning from their experiences and learning opportunities. This involves understanding the value of their experiences, how to articulate that value, and how to transfer it to workplace performance. The four pillars of the framework are set out below (and in Figure 1):

- AWARENESS: Employability is understood as the development of both discipline knowledge and skills, as well as personal attributes that guide workplace performance

- EXPERIENCES: Engaging with a range of curricular, co-curricular, and extracurricular experiences helps to develop employability

- LEARNING: Reflecting on experiences realises individual employability and, therefore, the value of the experience

- TRANSFER: Effectively communicating their employability in the recruitment process and applying it in the workplace translates learning into performance (i.e. graduates articulating their value and transferring it to professional contexts).

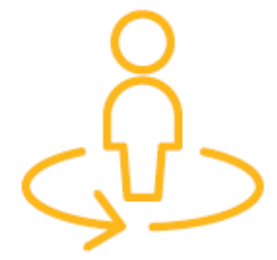

Awareness

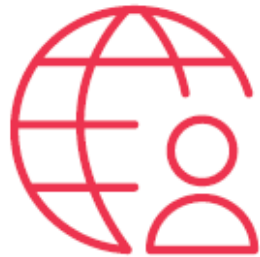

Experiences

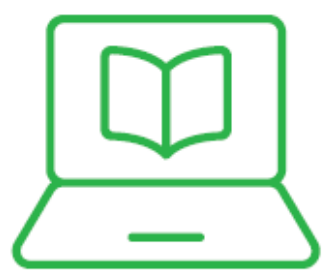

Learning

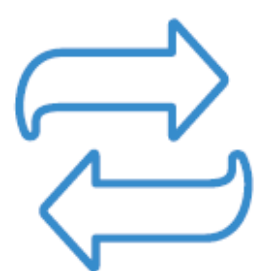

Transfer

Figure 1: The University of Queensland Employability Framework

(The University of Queensland, 2015)

The first pillar stems from the need to raise awareness of employability as a learning process that involves more than just development of degree knowledge and skills. This pillar addresses the conceptual confusion that still exists around employability that seeks to differentiate employability from the act of securing a job (Tomlinson, 2017). The second pillar is informed by the established value of experiences both within and outside formal settings for employability (Holmes, 2013; Jackson, 2016; Trede et al., 2012) and the use of non-professional experiences by recruiters to make selection decisions (Caballero \& Walker, 2010). The third and fourth pillars reflect the approach to employability as a learning process, underpinned by adult learning (Jarvis, 2006) and experiential learning theories (Kolb, 1984). The pillars reflect the challenge that graduates often face in 
understanding and articulating the value of their experiences (Reid, 2015), particular extracurricular, unstructured experiences such as international study (Forsey, Broomhall, \& Davis, 2012; Wong, 2015). Research shows that returned international study participants face difficulties applying their learning to professional contexts (Oguro \& Mueller, 2020). This finding could be applied to any extra-curricular or informal learning experience, given the lack of curricular structure of such experiences and the difference and distance between the learning context and the application of the learning.

\section{The SEAL reflective process}

The framework established the vital role that engaging with a range of experiences plays in employability development (Dacre Pool \& Sewell, 2007) and the meaning-making process that turns experiences into learning (Reid, 2020). Early operationalisation of the framework involved working in partnership with students in post-program workshops. The workshops were designed to help students unpack their experiences and link them to their employability (Reid, 2015). This aligned with research on the challenges students face in articulating their employability (Forsey et al., 2012; Wong, 2015), thus demonstrating the need for a structured process for making meaning from experiences for employability learning. Moreover, as a study by Tomasson Goodwin, Goh, Verkoeyen and Lithgow (2019) suggests, it is possible to teach students to articulate their employability.

Creating a structured reflective process for employability learning acknowledges the challenges students often face when undertaking reflective writing, and the need for students to be taught to think and write in this way (Newcomb, Burton, \& Edwards, 2018). A structure that steps students through their reflections is aimed at shifting thinking from descriptive to critically reflective, by giving students the chance to be more consciously aware of their experiences (Bourner, 2003). It was intended that a structured learning process would not only benefit students in their employability development but would also address the challenges that academic staff often face in teaching and assessing reflective writing (Bourner, 2003). The reflective process was aimed at supporting students to learn from experiences for employability development, but it was designed so that it could be used for reflective practice in a range of contexts.

The development of the structured learning process was an iterative and co-creative, where experiences working with students were aligned to experiential learning theory and Peter Jarvis's (2006) conceptualisation of the learning process. The goal was for the approach to be meaningful to students and not solely a theoretical frame for employability learning. The structured process developed was conceptualised around four meaning-making steps - Situation, Effect, Action and Learning - expressed as the acronym, SEAL (see Figure 2). The process allows students to consider:

- The particular development opportunity (the Situation of SEAL, or task, activity, event, experience and why it was a learning opportunity).

- The challenges or new experiences faced and how they impacted the learner (the Effect of SEAL).

- What the learner did to deal with the challenge or new experience and why they did this (the Action of SEAL).

- The learner's reflection on what they gained from the experience (the Learning of SEAL). The emphasis in the learning part of the process is on how the experience contributed to the student's personal and professional development and how it may guide future thought and action. The Learning part of SEAL is then used as the basis for identifying the skills or attributes that were developed or enhanced as a result of the experience, and then how they relate to workplace performance. 


\section{SITUATION}

What was the new experience or challenge you faced and what happened to you?

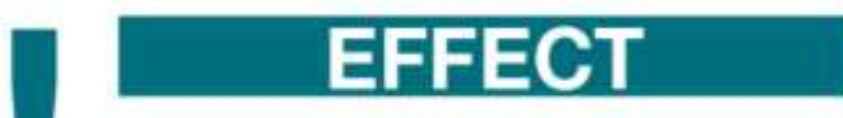

What impact did it have on you and what were the consequences of this impact?

\section{ACTION}

What action did you take to deal with the new situation and any challenges, and why did you do this?

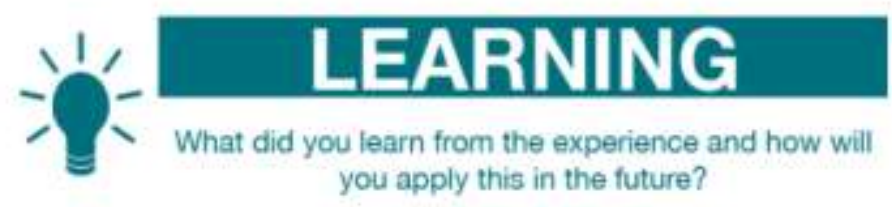

\section{Figure 2: The SEAL Reflective Process}

(The University of Queensland, 2015)

The SEAL reflective process is underpinned by Kolb's (1984) conceptualisation of the experiential learning process. It acknowledges Jarvis's $(2006 ; 2018)$ contention that learning always begins with experiencing a social situation, where the learner interacts with their life-world and they have a concrete experience (Kolb, 1984) (the Situation step in SEAL). In this way SEAL is intentionally utilised to construct and articulate learning from experiences (particularly in extra-curricular spaces) for a defined purpose. This speaks to Morris's (2020) suggested modification of Kolb's (1984) concept of concrete experience as contextually-rich concrete experience, recognising that knowledge is situated in context that emphasises place and time. It is acknowledged that the meaning-making parts of Kolb's model represented in SEAL by the Effect, Action and Learning steps are socially and contextually influenced (i.e. to support students to construct and articulate employability learning in the language of skills). Revisions of Kolb's model by Morris (2020) emphasise the context-specific nature of the reflections and conceptualisations of experiential learning and SEAL mirrors these revisions.

\section{Situation}

The Situation step of SEAL reflects the work with students which revealed that students needed a starting point for their meaning-making work to raise their awareness of their experiences as a learning opportunity and understand what the learning context meant to them. During postprogram workshops, students were asked to brainstorm the things that had happened to them 
during those experiences that they felt were personally significant. This brainstorming work demonstrated the value of establishing a conceptual centre for the students' meaning-making work (Reid, 2020) and identifying the stimulus for learning.

The awareness of a situation that characterises an experience may be stimulated by something that causes learners to question their assumptions about themselves and their worlds (Merriam \& Bierema, 2013) or creates a sense of disjuncture (Jarvis, 2010) or inner discomfort or perplexity (Brookfield, 1987).

\section{Effect}

The Effect step of SEAL gives students the chance to reflect on how the situation created personal impact or how and why it may have stimulated growth, framed by the nature of the experience and time and place (Morris, 2020). Learning involves making meaning of an experience by converting the learner's bodily sensations or reactions to episodic experiences into mental meanings (Jarvis, 2006). These mental meanings help explain an experience to the learner, i.e. they render the experience coherent, shaped by the learner's socially-constructed frame of reference (Mezirow, 2000), and social, intellectual, and physical engagement with experiences (Jordan, Gagnon, Anderson, \& Pilcher, 2018). These ideas align with developments in adult learning theory that look beyond just cognitive processes to acknowledge the place of body and mind in the learning process (Dirkx, 2001; Merriam, 2017).

\section{Action}

The Action step of SEAL further acknowledges that the learner is responsive to their world and the activities that happen around them through thoughts, feelings and actions (Jarvis, 2006). Responses to experiences are a product of the learner's social world, using socially-acquired language, so that interpretations of experiences reflect that world (Jarvis, 2018). Meaning-making in relation to actions taken to mitigate or handle the challenges faced in a situation allows the learner to evaluate their actions to determine if those actions produced a desirable outcome and if not, how they may react differently if faced with a similar challenge in the future. The Action step allows learners to start to consider how they might test out their learning in subsequent concrete experiences (Kolb, 1984; Morris, 2020).

\section{Learning}

The final step, Learning, is where learners understand and articulate how their contextually-rich experiences (Morris, 2020) have contributed to their personal and professional growth. The Learning step asks students to translate that learning into professional settings, giving them the chance to start thinking about how they might act pragmatically (Morris, 2020) in active experimentation (Kolb, 1984) with new concrete experiences. When students experience informal activities such as study abroad, volunteering, or leadership programs, making meaning of these experiences supports students to arrive at new understandings of their identities and capabilities (Reid, 2020) and what they can offer to an employer (de Blaquiere, et al., 2019). Students were asked to consider how their learning may align with the language of skills that employers and recruiters use to make judgements on role suitability (Tomlinson, 2017). This idea acknowledges that employability is more than just skills (Holmes, 2013), however confidence to articulate employability using the language of skills is crucial for success. This approach provides parameters for the reflection process with the aim of assisting students to unlock employability learning. It is important to provide this support as students do not know to reflect automatically and must be taught how to do so (Lutterman-Aguilar \& Gingerich, 1992, p. 45). The Learning part of SEAL is a vital culmination step for framing students' employability stories (de Blaquiere et al., 2019). 
The SEAL reflective process allows students to take their experiences and evaluate why they might have learning potential and how those experiences had an effect on them. They are able to analyse their thoughts and actions in different situations and consider how they may do things differently in the future. The reflective process asks students to respond to searching questions (Bourner, 2003) (see Table 1 below). Using meaning-making work to create employability narratives helps students to validate their identities as employable graduates and provides resources to draw on in the recruitment process (de Blaquiere et al., 2019). The process underpins the concept of self-perceived employability (SPE) which is usually applied in the context of the transition between education and work to indicate an individuals' sense of their own situation and opportunities (Rothwell \& Rothwell, 2017).

Below is an example of a student's reflection using SEAL with the transcript of the reflection as it was provided verbally. Commentary on the students' use of the stages of SEAL is also provided.

\section{Table 1: An Example SEAL Reflection}

\begin{tabular}{|c|c|}
\hline $\begin{array}{l}\text { What was the } \\
\text { situation in } \\
\text { which you } \\
\text { found } \\
\text { yourself? }\end{array}$ & $\begin{array}{l}\text { I was asked to present a short segment of a presentation for [university name and } \\
\text { study abroad program], the exchange program here at the university. I just had to } \\
\text { cover things like money, transportation, organising your accommodation once you } \\
\text { get there. They had asked me to do it because l've previously been on exchange, and } \\
\text { they also asked me and another girl if we could just give some of our top tips. } \\
\text { The student identified giving a presentation as a potential learning opportunity, i.e. } \\
\text { the stimulus for the student's meaning-making work, or their contextually-rich } \\
\text { concrete experience (Morris, 2020). }\end{array}$ \\
\hline $\begin{array}{l}\text { What effect } \\
\text { did the } \\
\text { situation have } \\
\text { on you? }\end{array}$ & $\begin{array}{l}\text { I must admit I was a little bit nervous beforehand. I'd never presented in front of } \\
\text { such a large cohort. It was an auditorium full of students, probably about maybe } 300 \\
\text { students. And I was representing [university name], so I had to make sure that I was } \\
\text { covering all the information that the coordinator had given me because she'd } \\
\text { actually asked me to say specific things, and then I could just add the little bit for } \\
\text { myself on my personal experiences. } \\
\text { Originally, when she asked me to do it, I was pretty excited about it because I love } \\
\text { talking about my exchange experience, but once I was in the auditorium and I saw all } \\
\text { of the students there, it really started to hit me what I was about to do. My heart was } \\
\text { beating out of my chest, and my palms were getting a little bit sweaty. I was sitting } \\
\text { up the front, and our segment was in the middle of the presentation, so I was } \\
\text { watching the whole presentation unfold. My part was getting closer and closer. Yes, } \\
\text { so I think the nerves sort of hit you, and then you start running through your head, } \\
\text { "Have I done everything right? Am I going to cover everything?" Yes, it's a little bit } \\
\text { daunting. } \\
\text { One of my majors is drama, so I have experience like on the stage and acting in front } \\
\text { of people. Definitely, the nerves hit you in the beginning, but once you get up there } \\
\text { and you just start rolling with it, it's fine. } \\
\text { Here the student describes the nervousness they felt giving the presentation. This } \\
\text { reaction to the situation created what Brookfield (1987) calls an inner discomfort or }\end{array}$ \\
\hline
\end{tabular}




\begin{tabular}{|c|c|}
\hline & $\begin{array}{l}\text { perplexity, forming the stimulus for the learning the student gained from the } \\
\text { experience. }\end{array}$ \\
\hline $\begin{array}{l}\text { What action } \\
\text { did you take } \\
\text { to deal with } \\
\text { the situation? } \\
\text { Why did you } \\
\text { take that } \\
\text { action? }\end{array}$ & $\begin{array}{l}\text { Well, originally, before I went into the auditorium, I was given the notes by the } \\
\text { coordinator of what she would like me to say, and I just went through them and } \\
\text { really read over them, made sure that I knew the content that I was supposed to } \\
\text { deliver. I highlighted, like, the really important parts there that I wanted to make } \\
\text { sure that I said, and then I thought of my top tips before I went into the auditorium } \\
\text { and just wrote them down in the margins on the PowerPoint slides so that I knew } \\
\text { what I was going to say so I wasn't standing there um-ing and oh-ing. Once I was in } \\
\text { the auditorium and my heart was beating really fast, I just sort of - I had a bottle of } \\
\text { water with me. I just took a sip, sips of water, had to take some deep breaths, just } \\
\text { sort of some self-talk, just reassuring myself that I'd been asked to do this for a } \\
\text { reason, so I could do it. } \\
\text { Here the student describes the actions they took to mitigate the nervousness of giving } \\
\text { a presentation. These actions represent the student's response to the context of the } \\
\text { experience and how the experience created personal impact in that time and place. } \\
\text { The student was able to transform the reaction to the situation into actions that } \\
\text { framed the learning they gained from the experience. }\end{array}$ \\
\hline $\begin{array}{l}\text { What did you } \\
\text { learn from the } \\
\text { experience? }\end{array}$ & $\begin{array}{l}\text { One of the best things that I took out of that experience was that I did have to } \\
\text { volunteer for that presentation, so I had to put my hand up and say, "Yes, it's scary, } \\
\text { but I'm going to give it a go." I definitely think that has given me the confidence to } \\
\text { put my hand up for other things. I have been asked to be on a panel for a symposium } \\
\text { for [university name]. That is also daunting, and there will obviously be more learning } \\
\text { involved because I will have to actually organise my own presentation for that. I have } \\
\text { also recently been on an internship in [city] with [place of internship] where I had to } \\
\text { speak in another language. } \\
\text { That was extremely challenging, but I guess if you throw yourself into the deep end } \\
\text { and you know that the learning is going to outweigh the nerves, and the experience } \\
\text { is going to be totally worth it, then you're not so afraid to put your hand up for things } \\
\text { anymore. } \\
\text { I think, just in general having this - having the experience itself, it just sort of puts you } \\
\text { in this position where you realise that you sort of can do anything. It doesn't matter } \\
\text { how daunting or challenging you think something is going to be, if you give it a go, } \\
\text { everything is going to work out. You're going to find things within yourself that you } \\
\text { didn't know that you could do, or people are going to be there along the way to help } \\
\text { you, and you're just going to keep growing and growing and growing. } \\
\text { Here the student articulates what they "took out of that experience" and how they } \\
\text { will take the learning they gained forward and apply it to new concrete experiences. } \\
\text { They have an example to give to an employer for a job application and/or recruitment } \\
\text { interview of how they took a challenge and turned it into a learning experience. }\end{array}$ \\
\hline
\end{tabular}

(SEAL reflection reproduced with permission from the student.) 


\section{Implementation of SEAL}

The first use of SEAL came in late 2014, when working collaboratively with UQ students, who had recently returned from a semester of study overseas, to pilot the reflective process in voluntary post-experience employability workshops (Reid, 2015). This pilot work showed that the reflective process contributed to students' understanding of the value of non-work-based experiences to their employability development. It was also found that SEAL enabled students to identify the capabilities and attributes they had developed through their experiences more easily. In particular, there was an emphasis on how the process helped students to better articulate the value of their experience to a potential employer and how to differentiate themselves. Students also indicated that they would use the tool in future with other learning opportunities (Reid, 2015).

On conclusion of the pilot, regular provision of the post-experience workshops for returning study abroad students was implemented. The workshops were also gradually incorporated into the delivery of other extracurricular programs, including Summer and Winter Research Program, Career Mentoring, and Student-Staff Partnerships programs. These post-experience employability workshops continue to be a core component of these programs.

The work on UQ's student employability framework was extended in 2015 following its endorsement by the university's Student Experience Committee. The Committee recognised that the experiential learning focus of the framework aligned with the university's teaching and learning and research approach, and it was subsequently incorporated into the 2016-2020 institutional student strategy. Development of student employability was articulated in the strategy as a priority for the next four years.

A Massive Open Online Course (MOOC) was then designed and developed on the edX platform, the first employability course to be offered on that platform. The course, EMPLOY101x Unlocking your employability, was launched in January 2016 and to date over 57000 learners across the world have enrolled. The course was based on the framework and created modules that stepped students through the four stages of employability development that the framework sets out. The SEAL selfreflective process is a foundational element of the course and is used to teach students to make meaning of their experiences for employability learning.

From 2017, the focus has been on embedding employability in the curriculum, working with academic staff to adopt SEAL as the mechanism through which students could self-reflect on their experiential learning activities (i.e. Work Integrated Learning) to make meaning from them for employability learning. Initially, a variation of the post-experience workshop was delivered in tutorials, but through the development of teaching materials adapted from the MOOC, staff training sessions and resources around the use of SEAL, staff were able to use SEAL without being reliant on the workshops. Staff have been supported to implement SEAL, including close liaison with Student Employability Centre staff and the provision of staff development workshops. A rubric was created for assessing SEAL and is included in the teacher resources developed for implementing the employability framework. Written exemplars are used in the MOOC and in the accompanying teaching resources and there are videos in $\mathrm{MOOC}$ that showcase students reflecting on experiences using SEAL.

To date, the focus has been on evaluating the reach of SEAL and other MOOC resources across UQ and beyond. At UQ, the SEAL self-reflective process has since been used in a variety of ways within the curriculum to identify and articulate employability learning from activities. The dual Nursing and Midwifery program in the School of Nursing, Midwifery and Social Work had historically used a selfreflection tool for critiquing critical incidents to evaluate competency achievements for accreditation processes across the program. In 2017 they replaced this with the SEAL process to enable students to identify the development of complementary personal qualities and attributes in addition to the particular competencies that students must evidence for accreditation. The Bachelor of Criminology and Criminal Justice program have introduced SEAL in a first year Criminology course. In this course, 
students are taught the SEAL process and then they apply it to their classroom activities. This early introduction to the process sets the students up to reflect on their employability throughout the rest of their studies. The School of Pharmacy has used SEAL in a final year course to focus on understanding how the capabilities that the students have identified from their experiences can be put to use effectively in their professional capacity as Pharmacists. There is a strong focus in the program on lifelong learning and on developing ongoing and habitual reflective practice. Other disciplines at UQ consistently use the SEAL self-reflective process to structure student reflection on Work Integrated Learning activities (predominantly placements and industry projects). These include Business Management, Education, Journalism, Environmental Management, Tourism, Speech Pathology, Economics and Finance, and Engineering.

Data shows 12499 student encounters with SEAL between 2016 and 2020. The existing and emerging data on these encounters with SEAL is being used to investigate staff and student perspectives on the value of the process for employability learning. Encounters with SEAL include students using the process for WIL reflections, when studying the MOOC as a course requirement, and through participating in a range of co- and extra-curricular activities. Students need to submit reflections on their experiences to claim those experiences for the university's employability award. Students may use SEAL across several curricular and co-and extra-curricular activities and can retain their reflections within an ePortfolio, both during study and after graduation to inform their employability narratives in the recruitment process and into professional roles and/or entrepreneurial endeavours.

The resources are open-source material. It was always intended they be freely available, in alignment with the researchers' ethical and moral stance on the importance of education. The MOOC is a free course on the edX platform and the university's website contains information on the institutional framework and SEAL. It is typically difficult to accurately record the use and implementation of open-source educational materials. This work has been disseminated at a number of academic and professional conferences and other networking events worldwide. Through these opportunities and as practitioners in the field, it has been noted that other institutions around Australia, including high schools, have adopted SEAL and are using the MOOC resources, including Macquarie University and the Australian Catholic University. International higher education providers are also using the materials, including in an online course for all commencing postgraduate students at The University of Exeter Business School in the UK, as training material for doctoral students at the Institut de Science des Matériaux de Mulhouse in France, and within an introductory employability course within the Faculty of Arts at the University of Auckland. SEAL is also used by international internships provider The Global Students in Malaysia to support students to understand the value of their international internship. Future work will investigate the efficacy of SEAL as a reflective process for employability learning.

\section{Conclusion}

It has been argued that universities should bear some responsibility for assisting students to identify and articulate their employability (Tomasson Goodwin et al., 2019), to bridge what Joy, Shea and Youden-Walsh (2013) describe as the 'articulation of skills' gap. Identifying and articulating employability involves making meaning from learning experiences, including those that sit outside formal settings, for ongoing personal growth (Reid, 2020). The application of employability learning to professional contexts (including recruitment) is vital for graduates, however it is important to recognise that this is a challenging and complex process. Some students find it difficult to make the connection between an experience (such as international study) and employability development and the professional applications of their learning (Oguro \& Mueller, 2020). The SEAL reflective process was developed in response to these challenges. The process responds to the call for universities to provide meaningful pedagogical processes for employability development (Green, King, \& Gallagher, 2019; Oguro \& Mueller, 2020). 
It is important to acknowledge the problematic nature of measuring life-experience learning (Behle, 2020) and the often-intangible outcomes of experiences like international study (Cushing et al, 2019). Similarly, the challenges that students often face when undertaking reflective thinking and writing (Newcomb, Burton \& Edwards, 2018) and the difficulties that academic staff have with supporting students in their endeavours and assessing reflective writing (Bourner, 2003) must also be acknowledged. Holmes (2017) recognised that the idea of a set of skills and attributes is inherent in most definitions of employability and that the employability research agenda has been focussed on lists of skills and attributes, despite the problematic nature of the production of these lists (Holmes, 2013). Employability, however, is an expected outcome for higher education (Matherly \& Tillman, 2019) and achieving this outcome in part involves students learning from a range of experiences to become employable.

Given the high stakes of the political economy of graduate employability for graduates, universities, and employers (Tomlinson, 2017), it is vital that students in higher education are able to understand and articulate their employability. The SEAL reflective process was developed to support all learners to make meaning from a range of learning experiences. The aim was to assist learners to identify the value of all of their experiences, so that they can articulate this value and transfer it into different places and spaces to demonstrate their employability. The reflective process was also developed to assist academic staff to support their students in reflective practice and provide a structured process for assessing reflective writing. The process affords personal responsibility to students for their personal and professional growth. It maximises learning opportunities so that graduates may become more than just a list of skills on a resume. They can become individuals who are empowered to embark on their career journeys with confidence in their potential to contribute to society and the economy through their professional endeavours.

\section{References}

Behle, H. (2020). Students' and graduates' employability: A framework to classify and measure employability gain. Policy Reviews in Higher Education, 4(1), 105-130. doi: 10.1080/23322969.2020.1712662

Boud, D., Cohen, R., \& Walker, D. (1993). Using experience for learning. Buckingham: SHRE and Open University Press.

Bourner, T. (2003). Assessing reflective learning. Education + Training, 45(5), 267-272. doi:10.1108/00400910310484321

Braun, V., \& Clarke, V. (2006). Using thematic analysis in psychology. Qualitative Research in Psychology, 3(2), 77-101. doi: 10.1191/1478088706qp063oa

Brookfield, S. (1987). Developing critical thinkers. San Francisco: Jossey-Bass.

Brown, P., Hesketh, A., \& Williams, S. (2003). Employability in a knowledge driven economy. Journal of Education and Work, 16(2), 107-106. doi: 10.1080/13639080305562

Caballero, C., \& Walker, A. (2010). Work readiness in graduate recruitment and selection: A review of current assessment methods. Journal of Teaching and Learning for Graduate Employability, 1(1), 13-25. doi: 10.21153/jtlge2010vol1no1art546

Clark, G., Marsden, R., Whyatt, J.D., Thompson, L., \& Walker, M. (2015). It's everything else you do...Alumni views on extracurricular activities and employability. Active Learning in Higher Education, 16(2), $133-147$. doi: $10.1177 / 1469787415574050$

Cole, D. \& Willox, D. (2021). Broken employability metrics need a post-pandemic revamp. The Times Higher Education. Retrieved from https://www.timeshighereducation.com/opinion/broken-employabilitymetrics-need-post-pandemic-revamp

Curran, S. (2007). The career value of education abroad. International Educator, November-December, 48-52.

Cushing, D.F, Pennings, M., Willox, D., Gomez, R., Dyson, C., \& Coombs, C. (2019). Measuring intangible outcomes can be problematic: The challenge of assessing learning during international short-term study experiences. Active Learning in Higher Education, 20(3), 203-217. doi: 10.1177/1469787417732259

Dacre Pool, L., \& Sewell, P. (2007). The key to employability: Developing a practical model of graduate employability. Education + Training, 49(4), 277-289. doi: 10.1108/00400910710754435

Dacre Pool, L. (2017). Developing graduate employability: The CareerEDGE model and the importance of emotional intelligence. In M. Tomlinson \& L. Holmes (Eds.), Graduate employability in context: Theory, research and debate (pp. 317-338). London: Palgrave Macmillan. doi: 10.1057/978-1-137-57168-7 
de Blaquiere, G.E., Nolan, J.E., \& Wray, K. (2019). Joining up the dots: Telling the story of employability: How can students in higher education be supported to better understand and articulate their employability. Journal of Teaching and Learning for Graduate Employability, 10(2), 15-35. doi: 10.21153/jtlge2019vol10no2art699

Department of Education, Skills and Employment. (2020). Job-ready graduates package. Retrieved from https://www.dese.gov.au/job-ready

Dirkx, J.M. (2001). The power of feelings: Emotion, imagination and the construction of meaning in adult learning. New Directions for Adult and Continuing Education, 89, 63-72.

Erichsen, E.A. (2011). Learning for change: Transforming international experience as identity work. Journal of Transformative Education, 9(2), 109-133. doi: 10.1177/2F1541344611428227

Forsey, M., Broomhall, S., \& Davis, J. (2012). Broadening the mind? Australian student reflections on the experience of overseas study. Journal of Studies in International Education, 16(2), 128-139. doi: $10.1177 / 1028315311407511$

Fry, H., Ketteridge, S., \& Marshall, S. (Eds.). (2009). A handbook for teaching and learning in higher education: Enhancing academic practice (3rd ed.). New York: Routledge.

Green, W., King, E., \& Gallagher, J. (2019). How can international learning experiences enhance employability? Critical insights from new graduates and the people who employ them. In R. Coelen \& C. Gribble (Eds.), Internationalisation and employability in higher education (pp. 25-38). London: Routledge.

Holmes, L. (2013). Competing perspectives on graduate employability: Possession, position or process? Studies in Higher Education, 38(4), 538-554. doi: 10.1080/03075079.2011.587140

Holmes, L. (2017). Graduate employability: Future directions and debate. In M. Tomlinson \& L. Holmes (Eds.), Graduate employability in context: Theory, research and debate (pp. 359-370). London: Palgrave Macmillan. doi: 10.1057/978-1-137-57168-7

Huta, V. (2017). Meaning as subjective experience. Journal of Constructivist Psychology, 30(1), 20-25. doi: 10.1080/10720537.2015.1119088.

Jackson, D. (2016). Re-conceptualising graduate employability: The importance of pre-professional identity. Higher Education Research and Development. 35(6), 925-939. doi: 10.1080/07294360.2016.1139551

Jarvis, P. (1987). Adult learning in the social context. Kent: Croom Helm.

Jarvis, P. (2006). Towards a comprehensive theory of human learning. London: Routledge.

Jarvis, P. (2018). Learning to be a person in society: Learning to be me. In K. Illeris (Ed.), Contemporary theories of learning: Learning theorists...in their own words ( $2^{\text {nd }}$ ed., pp. 15-28). London and New York: Routledge.

Jordan, K.A., Gagnon, R.J., Anderson, D.M., \& Pilcher, J.J. (2018). Enhancing the college student experience: Outcomes of a leisure education program. Journal of Experiential Education, 41(1), 90-106. doi:10.1177/1053825917751508

Joy, R., Shea, R, \& Youden-Walsh, K. (2013). Advancing career integrated learning at Memorial. Paper presented at Cannexus 13, Ottawa, January 28-30.

Kaye, L.K., \& Bates, E.A. (2017). The impact of higher fees on psychology students' reasons for attending university. Journal of Further and Higher Education, 41(3), 379-392. doi: 10.1080/0309877X.2015.1117597

Kegan, R. (1982). The evolving self: Problem and process in human development. Cambridge MA: Harvard University Press.

Kolb, D. (1984). Experiential learning: Experience as the source of learning and development. Englewood Cliffs NJ: Prentice Hall.

Lau, H.H., Hsu, H.Y., Acosta, S., \& Hsu, T.L. (2014). Impact of participation in extra-curricular activities during college on graduate employability. Educational Studies, 40(1), 26-47. doi: 10.1080/03055698.2013.830244

Matherly, C., \& Tillman, M. (2019). Linking learning abroad to employability. In R. Coelen \& C. Gribble (Eds.), Internationalisation and employability in higher education (pp. 11-24). London: Routledge.

Merriam, S.B (2017). Adult learning theory: Evolution and future directions. PAACE Journal of Lifelong Learning, 26, 21-37.

Merriam, S.B., \& Bierema, L.L. (2013). Adult learning: Linking theory and practice. San Francisco CA: John Wiley \& Sons.

Mezirow, J., \& associates. (2000). Learning as transformation: Critical perspectives on a theory in progress. San Francisco CA: Jossey-Bass.

Montrose, L. (2002). International study and experiential learning: The academic context. Frontiers: The Interdisciplinary Journal of Study Abroad, 8(1), 1-15. doi: 10.36366/frontiers.v8i1.91

Morris, T.H. (2020). Experiential learning: A systematic review and revision of Kolb's model. Interactive Learning Environments, 28(8), 1064-1077. doi: 10.1080/10494820.2019.1570279

Reid, A., Richards, A., \& Willox, D. (2021). Connecting experiences to employability through a meaning-making approach to learning. Journal of Teaching and Learning for Graduate Employability, 12(2), 99-113. 
Newcomb, M., Burton, J., \& Edwards, N. (2018). Pretending to be authentic: Challenges for students when reflecting writing about their childhood for assessment. Reflective Practice 19(3), 333-344. doi: 10.1080/14623943.2018.1479684

Nghia, T.L.H. (2017). Developing generic skills for students via extra-curricular activities in Vietnamese universities: Practices and influential factors. Journal of Teaching and Learning for Graduate Employability, 8(1), 22-39. doi: 10.21153/jtlge2017vol8no1art624

Oguro, S., \& Mueller, B. (2020). Learning abroad and graduate employability: Challenges articulating

international learning outcomes. In E. Heinrich \& R. Bourke (Eds.), Research and development in higher education: Next generation, higher education: Challenges, changes and opportunities (vol. 42, pp. 85-93). Sydney NSW: HERDSA.

Ortlieb, E. (2015, February 12). Just graduating from university is no longer enough to get a job. The Conversation. https://theconversation.com/just-graduating-from-university-is-no-longer-enough-to-get-ajob-36906

Park, C. (2017). Distinctions to promote an integrated perspective on meaning: Global meaning and meaningmaking processes. Journal of Constructivist Psychology, 30(1), 14-19. doi: 10.1080/10720537.2015.1119082

Purcell, K., Elias, P., Atfield, G., Behle, H., Ellison, R., \& Luchinskaya, D. (2012). Futuretrack 4: Transitions into employment, further study and other outcomes. Warwick UK: Warwick Institute for Employment Research

Reid, A. (2015, November). Translating experience: A framework for developing graduate employability. Paper presented at the Australian Association for Research in Education Conference, Perth.

Reid, A. (2020). The connection between experience and learning: Student perspectives on the significance of international study. (Doctoral dissertation, University of Queensland, Brisbane, Australia). doi:10.14264/1988281

Richardson, S. (2004). Employers' contribution to training. Adelaide: NCVER.

Rothwell, A., \& Rothwell, F. (2017). Graduate employability: A critical oversight. In M. Tomlinson \& L. Holmes (Eds.), Graduate employability in context: Theory, research and debate (pp. 41-63). London: Palgrave Macmillan. doi: 10.1057/978-1-137-57168-7

Seaman, J., Brown, M., \& Quay, J. (2017). The evolution of experiential learning theory: Tracing the lines of research in the JEE. Journal of Experiential Education, 40(4), NP1-NP21. doi:10.1177/1053825916689268

Strange, H., \& Gibson, H. (2017). An investigation of experiential and transformative learning in study abroad programs. Frontiers: The Interdisciplinary Journal of Study Abroad, 29(1), 85-100. doi:10.36366/frontiers.v29i1.387

The University of Queensland. (2015). EMPLOY101x Unlocking your employability. Retrieved from https://www.edx.org/course/unlocking-your-employability

Tomasson Goodwin, J., Goh, J., Verkoeyen, S., \& Lithgow, K. (2019). Can students be taught to articulate employability skills? Education + Training, 61(4), 445-460. doi: 10.1108/ET-08-2018-0186

Tomlinson, M. (2017). Introduction: Graduate employability in context: Charting a complex, contested and multi-faceted policy and research field. In M. Tomlinson \& L. Holmes (Eds.), Graduate employability in context: Theory, research and debate (pp. 1-40). London: Palgrave Macmillan. doi: 10.1057/978-1-13757168-7

Trede, F., Macklin, R., \& Bridges, D. (2012). Professional identity development: A review of the higher education literature. Studies in Higher Education, 37(3), 365-384. doi: 10.1080/03075079.2010.521237

Wong, E.D. (2015). Beyond 'it was great'? Not so fast. Frontiers: The Interdisciplinary Journal of Study Abroad, 26(1), 121-135. doi: 10.36366/frontiers.v26i1.36

Yorke, M. \& Knight, P.T. (2004). Embedding employability into the curriculum. York: The Higher Education Academy.

Yorke, M. (2006). Employability in higher education: What it is and what it is not. York: The Higher Education Academy.

Zittoun, T., \& Brinkmann, S. (2012). Learning as meaning-making. In N.M Seel (Ed.), Encyclopedia of the Sciences of Learning. Boston MA: Springer. doi: 10.1007/978-1-4419-1428-6_1851 